\title{
The Influence of Perceived Organizational Support and Internal Communication toward Work Engagement
}

\author{
Friyanka Sitorus \\ Universitas Sumatera Utara \\ Medan, Indonesia \\ Email: friyankasitorus@gmail.com
}

\begin{abstract}
Human resources become themain capital for labor-intensive industries. Further, work engagement has emerged as one of the most critical factors to create acompetitive advantage on human resource. Developing work engagement needs areciprocal relationship between organization and employee. The present study aimed to explore the influence of perceived organizational support and internal communication toward work engagement. Using quantitative approach with convenience sampling method, this study involves 201 permanent employees in a labor-intensive industry engaged in manufacturing. Data collection technique used was survey method by distributing the scale consisting of work engagement scale, perceived organizational support scale and internal communication scale. Multiple regression was utilized to analyze these research data. The result revealed that perceived organizational support and internal communication significant and positively influenced work engagement. It meant the higher level of work engagement the stronger organizational support perceived by theemployee and the more effective internal communication. The implication of this study will help theorganization in enhancing work engagement level on anemployee by optimizing perceived organizational support and internal communication effectiveness.
\end{abstract}

Keywords: Work Engagement, Perceived Organizational Support, Internal Communication, Labor-Intensive Industry

\section{INTRODUCTION}

In this era of globalization, organizations are faced with various challenges in running their business. These challenges could come from various aspects, whether internal or external, from economic, socio-cultural, political, legal, technological and infrastructure aspects. About the goals and objectives of the organization, this condition requires the organization to be able to demonstrate its best performance to remain competitive and even growing (Adeoye \& Elegunde, 2012).

To remain competitive, an organization must have some resources. The resources include physical resources, finance, marketing ability and human resources. Of the total resources, human resources are one of the most potential factors to provide a competitive advantage for the organization (Fisher, Schoenfeldt \& Shaw, 2006). To develop a strategy that places human resources as a competitive advantage, the ultimate goal must be to create engaged employees (Dale Carnegie \& Associates, 2012). Schaufeli and Bakker (2004) argue that organizations that have human resources with high work engagement can maintain and improve performance even though conditions around it are less conducive.
PT. $X$ is a labor-intensive company engaged in manufacturing of rubber processing with the results of tires for various motor vehicles. According to theinternal state of the company, it still encountered several problems that hinder the achievement of optimal company performance. One is illustrated by the complaints submitted by the customer, among others are product defects, packaging errors, and delivery.

Customer complaints related to product defects, product delivery errors and packaging indicate a lack of optimum performance. This is certainly closely related to the human resources owned by PT. X where the company is a laborintensive company that hangs its business process journey on the company's human resources.

According to Markos and Sridevi (2010), human resources with a disengaged employee will result in low commitment, low customer orientation, ahigh percentage of absenteeism and a tendency to make mistakes in work which then affect performance achievement organization (Markos \& Sridevi, 2010).

Meanwhile, Kular, Gatenby, Rees, Soane, and Truss (2008) argue that a high level of work engagement will produce positive results on the success of an organization where an organization with employees with high levels of job 
attachment is predicted to experience improvement in customer satisfaction, productivity and profitability. Even in less conducive conditions, employees with high work engagement can maintain and improve their performance (Schaufeli and Bakker, 2004).

Thus, it is important for PT. X to find out the extent to which employees' work engagement level where human resources are one of the most potential factors to provide a competitive advantage for the organization to survive in global market competition. (Fisher, Schoenfeldt \& Shaw, 2006).

Eisenberger, Malone, and Presson (2016) argue that the perceived organizational support is an important factor in the effort to develop work engagement within a company. This construct is important because of the increasingly competitive environment that makes employees more worried about the extent to which organizations pay attention to their well-being (Eisenberger et al., 2016).

Organizational treatment has a great impact on employee perceptions, and it will again redirect how the employee's treatment of the organization. This situation can ultimately affect the commitment and work engagement (Eisenberger, Armeli, Rexwinkel, Lynch, \& Rhoades, 2001).

In addition to the perceived organizational support, internal communication is also touted as one of the key drivers in building work engagement (Yates, 2006). Communication is one of the main factors of sustainability of an organization where almost all activities within the organization involve communication. In this case, organizations that have effective communication with their employees will have a higher level of work engagement (Baumruk \& Gorman, 2006; Yates, 2006).

Some other studies have also found that internal communication is found to have a positive relationship with work engagement and organizational commitment (Carriere \& Bourque, 2009; Taylor \& Elsey 2005; Sopow, 2008; Sudhakar \& Patil, 2006). In line with research by White, Vanc, and Stafford (2010) who also found that effective internal communication can enhance employees' sense of ownership and give employees a greater sense of responsibility to support organizations on a personal level.

Based on the above explanation, the researcher is interested to examine the influence of perceived organizational support and internal communication to work engagement in PT X. Considering that this company is a labor- intensive company that relies on its business process to human resources, it is important to see the work engagement level in order to ensure the company's success in facing global market competition.

\section{A. Work Engagement}

\section{THEORY}

The concept used in this study is work engagement. Schaufeli and Bakker (2004) define work engagement as a condition in which a person feels satisfied and has a positive mind in his work which is characterized by high vigor, dedication, and absorption in doing the work. Vigor is characterized by a work climate that is full of energy and mental resilience and a willingness to work more in working and surviving despite many difficulties. Dedication is characterized by full engagement in its work and feels its interests, enthusiasm, inspiration, pride, and challenges in its work. Absorption is characterized by a climate of concentration and preoccupation with the work, time passes quickly, and it is difficult to get away from the job.

There are several things that become factors of the emergence of work attachment within an organization. Robinson, Perryman \& Hayday (2004) indicate some factors below as an important factor affecting the level of work engagement, including a. Quality management, characterized by the attitude of managers who care about their employees, informative, give fair treatment, encourage employees to show their best performance, and give attention related to thecareer development of its employees; b. TwoWay and open communication within the organization; c. Effective cooperation between different departments and functions, as well as between management and trade unions; d. Focus on employee development; e. organizational commitment to employee well-being; and $\mathrm{f}$. justice regarding salaries and benefits that include comparisons both inside and outside the organization's environment.

\section{B. Perceived Organizational Support}

According to Eisenberger et al. (1986), perceived organizational support are defined as employees' perceptions of the extent to which organizations value their contributions and care about their well-being. Furthermore, Rhoades and Eisenberger (2002) define the perceived organizational support as an overall employee belief about the extent to which organizations value their contribution and care about their well-being. According to Rhoades and 
Eisenberger (2002), there are three pleasant treatments from organizations that could improve the perceived organizational support, namely rewards from the organization and conditions of work, support from supervisors and fairness.

The perceived organizational support has a direct impact on employee behavior within the organization. The ideology of exchange (exchange theory) and reciprocity (norms) inherent in the concept of organizational support, make employees feel obliged to repay the organization's treatment (Eisenberger et al., 1986; Eisenberger et al., 2001).Numerous studies have found a positive impact on the perceived organizational support towards employee satisfaction (Eisenberger, Cummings, Armeli, Lynch, 1997, Hussami, 2008; Asegale \& Eisenberger, 2003), organizational citizenship behavior (Asgari \& Samah, 2008; Miao \& Kim, 2010; Ali, 2009) and work engagement (Rich, Lepine and Crawford, 2010; Ram and Prahbkar, 2011; Dabke and Patole, 2014; Burns, 2016; Eisenberger, Malone and Presson, 2016).

\section{Internal Communication}

Goldhaber (1986) defines organizational communication as a process of creating and exchanging messages in a network of interdependent relationships to address an uncertain or ever-changing environment. In organizational communication, there are internal and external communications. Within the limits of this study, researchers used internal communications.

According to Goldhaber (1986), internal communication is the process of exchanging information between people within the organization, either horizontally or vertically to complete the work. Based on the concepts of some other experts, internal communication is a communication function specifically designed by the organization to build and foster relationships with internal stakeholders, resulting in emotional closeness embodied through useful engagement for the achievement of organizational goals (Woodruffe 1995, Doorley \& Garcia, 2007; Thereof, Welch \& Jackson, 2007).

Dennis (1975) developed a study of communication practices within an organization that describes the quality of objective experience of the internal environment of an organization. This study includes the perception of organizational members of the message and the relationship of messages to events that occur within the organization. In his research, Dennis
(1975) found four dimensions in the internal communication practice of an organization, namely: superior-subordinate communication, quality of information, opportunities for upward communication dan reliability of information.

The effectiveness of communication that takes place within an organization gives a good impact to the organization such as enhancing the reputation and credibility of the organization (Dawkins, 2004; Hannegan, 2004; Tucker, Meyer \& Westerman, 1996), increasing employee confidence (Ragusa, 2010); improve the behavior of supporting organizations (De Ridder and Human, 2004, Allen \& Meyer, 1996) and improve work engagement (Hardaker \& Fill, 2005; Sopot, 2008; Sudhaker \& Patil, 2006; White et al, 2010; Carriere \& Bourque, 2009; Thomson and Hecker, 2000).

\section{Hypotheses}

From the previous description, this study has three hypotheses, namely:

H1: There is a positive effect of perceived organizational support towards work engagement.

H2: There is a positive effect of internal communication towards work engagement.

H3: There is a positive effect of perceived organizational support and internal communication toward work engagement.

\section{METHOD}

This research used thequantitativeapproach to convenience sampling technique for research sampling. A total of 201 permanent employees at PT. X was included as a participant in the study. Methods of data retrieval conducted in this study is a survey method by spreading the scale that consists of the work engagement scale, perceived organizational support scale and internal communication scale of each consist of 7 point scale.

The researcher used 7 point scale at each research scale with the aim to overcome the midpoint limitations on the Likert usage in the answer choices. Cummins \& Gullone (2000) suggest that midpoint limitations can be reduced by increasing the scale sensitivity. Increasing the scale sensitivity means increasing the number of scale options. Some researchers suggest that increased scale sensitivity may decrease the tendency to choose the midpoint (Matell \& Jacoby, 1972; Cummins \& Gullone, 2000; Tsang, 2012). It is further said that midpoint choice tends to be more common on a 3 point scale and 
a 5 point scale, but is reduced on a scale of 7 points.

Work engagement scale consists of 14 items with 7 choices of answers ranging from never to always. The reliability of the scale of work attachment obtained from the test using Cronbach's Alpha method is 0.847 with a construct validity value of 0.50 to 0.80 .

Perceived organizational support consists of 13 items with 7 choices ranging from strongly disagree to agree strongly. Reliability of organizational support perception scale obtained from atest using Cronbach's Alpha method is 0.839 with construct validity value from 0.570 to 0.889 .

Internal communication scale consists of 14 items with 7 choices of answers ranging from strongly disagree to agree strongly. Internal communication scale reliability obtained from the test using Cronbach's Alpha method is 0.873 with construct validity value from 0.503 to 0.847 .

Data analysis method used to test the hypothesis in this research is astatistical analysis that is multiple regression by using SPSS version 16 for windows. Before the hypothesis testing is done first test assumptions that also use the help program SPSS version 16 for windows. The assumption test is the normality test, linearity test, heteroscedasticity test, autocorrelation test and multicollinearity test.

\section{RESULT}

In scoring norms at each study scale, researchers used three categories. The scale of work engagement has an average score of 57.94, where the score is classified as ahigh category which means that most research subjects have a high level of work engagement. The scale of perceived organizational support has an average of 57.11 where the score is classified as moderate, which means that most of the research subjects perceive the support provided by the company is in the medium category. Finally, the internal communication scale has an average of 68 where this score belongs to the medium category which means that most subjects judge that internal communication is quite effective.

The first hypothesis in this study is that there is a positive effect of perceived organizational support toward work engagement. Hypothesis testing is done using simple regression analysis. From the result of simple regression statistic test between theeffect of perceived organizational support (X1) toward work engagement (Y) is obtained aresult that perceived organizational support has asignificant positive effect on work engagement. Furthermore, the second hypothesis in this study is that there is a positive effect of internal communication toward work engagement. Hypothesis testing is also done using simple regression analysis. From the results of simple regression statistical test between the effect of internal communication (X2) toward work engagement $(Y)$ obtained the result that internal communication has a significant positive effect on work engagement. Finally, the third hypothesis in this study is that there is a positive effect of perceived organizational support and internal communication toward work engagement. Hypothesis testing is done using multiple regression analysis. From the result of multiple regression statistic tests between the effect of perceived organizational support (X1) and internal communication (X2) toward work engagement $(\mathrm{Y})$, it is obtained that the perceived organizational support and internal communication have a significant positive effect on work engagement.

\section{DISCUSSION}

The results of this study indicate that the perceived organizational support has a positive and significant effect on work engagement. This means that the stronger the organization's support perceived by the employees at PT.X, the higher the level of work engagement.

Perceived organizational support is employees' beliefs about the extent to which organizations value their contributions and care about their well-being. This perception reflects the belief that the organization intends to reward its employees, the organization values employees' contribution to the achievement of organizational goals and concerns the welfare of their employees (Eisenberger et al., 1986).

Rhoades and Eisenberger (2002) argue that the relationship formed between employees and organizations is a reciprocal relationship. In this case, organizations that create favorable conditions for their employees will benefit through the positive attitudes that will be provided by their employees. Employees who perceive the support provided by a strong organization will feel obliged to help the company achieve its goals.

In line with this research, PT. X which has rewarded employee contributions and paid attention to the welfare of its employees, building employee perceptions about the treatment that the company has provided. It is this that then foster obligations on employees to reply to the 
treatment they have received by growing a positive attitude towards his work which then called for work engagement.

Other studies also confirm that work engagement is a significant impact generated by theperceived organizational support. When employees feel that their welfare is noticed and their contributions are respected by the organization, they will try to show the spirit, dedication, and appreciation of work (Biswas \& Bhatnagar, 2013; Saks, 2006). In line with Rubel and Kee (2013) who found a positive and significant influence on the perceived organizational support on work engagement. In this case, the perceived organizational support can stimulate employees to be more attached to their role in work. These conditions make employees strive to achieve organizational goals by showing high levels of work engagement.

Subsequent findings indicate that internal communication has a positive and significant impact on work attachment. This means that the more effective internal communication that takes place in PT. X, the higher the level of work engagement. Similarly, on the contrary, ineffective internal communication will decrease the level of work engagement.

The results of this study are in line with Thomson and Hecker (2000) who found that the level of effectiveness of internal communication will positively affect employee engagement levels. The more effective internal communication perceived by employees, the higher the level of employee engagement. In this case, the quality of good internal communication will encourage an organizational supportive behavior that refers to a positive attitude toward the organization's strategic goals.

The results showed that the existence of twoway communication that runs effectively between superiors and subordinates. Some studies have also shown that effective communication between management and employees creates a higher work attachment. For example, a survey conducted by the Chartered Institute of Personnel and Development (2006) suggests that workers appreciate the opportunity given to them to share their opinions and opinions on management. This is a very important factor in encouraging work engagement. Furthermore, when management receives what employees are told about what is going on in the organization, then it can build a higher work engagement.

Furthermore, Alfes, Truss, Soane, Rees, and Gatenby (2010) argue that positive communication, especially the opportunities given to employees to voice their opinions is an important factor that affects the attachment of work. Opportunity to voice an opinion makes employees feel strongly involved in the organization and wants to participate more towards the organization (Budd, Gollan \& Wilkinson, 2010). Employees who experience a positive communication experience will see themselves as one with the organization (De Ridder \& Human, 2004). Thisis then manifested through his work where the employee who is satisfied with the opportunity given to him will be positive and show the work engagement (Ruck, 2012).

Truss, Soane, Edwards, Wisdom, Croll, and Burnett (2006) identified three factors that influence work engagement, namely the opportunity to express an opinion or views to superiors, obtain reliable information related to the company and have a manager who is committed to the organization. In line with this study where internal communication affects work engagement. The aspects of internal communication used in this study in line with the above invention that includes communication from superiors to subordinates, quality, and reliability of information and opportunities given to subordinates to communicate to superiors.

\section{CONCLUSION}

Based on the results obtained in this study, it can be concluded that (1) Perceived organizational support positively and significantly affect the work engagement on permanent employees at PT. X. This means the stronger support from PT. X perceived employee the higher the level of employee engagement; (2) Internal communication has a positive and significant impact on the employee's work engagement. This means the more effective internal communication that takes place in PT. X then the higher level of work engagement. Moreover, (3) Perceived organizational support and internal communication together have a positive and significant effect toward work engagement on permanent staff at PT. X. This means the stronger support from PT. X perceived by employees and the more effective internal communication that took place at PT. X then the higher level of work engagement.

\section{RECOMMENDATION}

In this study, the average research's subjects still perceive the organizational support they receive in the medium category, and there are 
still some employees who perceive it weak. This shows that PT. X still has achance to create strong perceived organizational support by increasing employees' support. Types of rewards such as salary, promotion, job enrichment, and the effect on organizational policies provided fairly will reinforce the perceived organizational support, which indicates a positive evaluation of the organization to employees.

Furthermore, based on the results of research, also known that the average research's subjects consider that the communication at PT. X is quite effective and there are still some who consider it less effective. This shows that PT. X still has a gap to improve the effectiveness of ongoing communication within the company to increase employee engagement levels. To improve the effectiveness of internal communication at PT.X can be realized by building an open communication between superiors and subordinates, the existence of transparency and reliability regarding information exchange related issues within the company as well as the opportunity given by the management to employees to voice their opinions.

\section{REFERENCES}

[1] Adeoye, A. O., \& Elegunde, A. F. (2012). Impacts of theexternal business environment on organizational performance in the food and beverage industry in Nigeria. British Journal of Arts and Social Sciences, 6(2), 194201.

[2] Alfes, K., Truss, C., Soane, E. C., Rees, C., Gatenby, M. (2010). Creating an engaged workforce, findings from the Kingston employee engagement consortium project, research report. London: Chartered Institute of Personnel and Development.

[3] Ali, N. (2009). Effect of perceived organizational support and leader-member exchange on organizational citizenship behavior. Journal of Social Science, 3(2), 53.

[4] Allen, N. J., \& Meyer, J. D. (1996). Affective, continuance and normative commitment to the organization: An examination of construct validity. Journal of Vocational Behaviour, 49(3), 252-276.

[5] Asegale, J., \& Eisenberger, R. (2003). Perceived organizational support and psychological contracts: A theoretical integration. Journal of Organizational Behavior, 24, 491-509.
[6] Baumruk, R., \& Gorman, B. (2006). Why managers are crucial to increasing engagement. Melcrum Publishing, 24-27.

[7] Biswas, S., \& Bhatnagar, J. (2013). Mediator analysis of employee engagement: Role of perceived organizational support, P-O fit, organizational commitment and job satisfaction. VIKALPA,38, 27-40.

[8] Budd, J. W., Gollan, P. J., Wilkinson, A. (2010) New approaches to employee voice and participation in organizations. Human Relations 63(3), 303.

[9] Burns, K. L. (2016). Perceived organizational support and perceived supervisor support as antecedents of work engagement. (Tesis). San Jose State University.

[10] Carriere, J., \& Bourque, C. (2009). The effects of organizational communication on job satisfaction and organizational commitment in a land ambulance service and the mediating role of communication satisfaction. Career Development International, 14(1), 29-49.

[11] Chartered Institute of Personnel and Development. (2006). Recruitment, retention, and turnover. Annual Survey Report, 1-39.

[12] Cummins, R. A., \& Gullone, E. (2000). Why we should not use 5-point Likert scales: The case for thesubjective quality of life measurement. Paper presented at the Proceedings, Second International Conference on Quality of Life, Singapore: National University of Singapore.

[13] Dabke, D., \& Patole, S. (2014). Predicting employee engagement: Role of perceived organizational support and perceived superior support.Tactful Management Research Journal, 3(1), 1-8.

[14] Dale Carnegie \& Associates. (2012). What drives employee engagement and why it matters. Dale Carnegie Training White Paper, 1-6.

[15] Dawkins, J. (2004). Corporate responsibility: The communication challenge. Journal of Communication Management, 9(2), 108-119.

[16] De Ridder, J. \& Human, A. (2004). Organizational communication and supportive employees. Resource Management Journal, 14 (3), 20-30.

[17] Dennis, H. (1975). The construction of a managerial communication climate inventory of use in complex organization. Paper presented at a meeting of the International Communication Association, Chicago, IN.

[18] Eisenberger, R., Armeli, S., Rexwinkel, B., Lynch, P. D., \& Rhoades, L. (2001). 
Reciprocation of perceived organizational support. Journal of Applied Psychology, 86, 42-51.

[19] Eisenberger, R., Cummings, J., Armeli, S., Lynch, P. (1997). Perceived organizational support, discretionary treatmentand job satisfaction. Journal of Applied Psychology, 82(5), 812-820.

[20] Eisenberger, R., Huntington, R., Hutchison, S., \& Sowa, D. (1986). Perceived organizational support. Journal of Applied Psychology, 71(3), 500-507.

[21] Eisenberger, R., Malone, G.P. \& Presson, W.D. (2016). Optimizing perceived organizational support to enhance employee engagement.SHRM-SIOP Science of HR Series, 1-22

[22] Eisenberger, R., Rhoades, L., \& Cameron, J. (1999). Does pay for performance increase or decrease perceived self-determination and intrinsic motivation? Journal of Personality and Social Psychology, 77, 10261040.

[23] Fisher, C. D., Schoenfeldt, L. F., \& Shaw, J. B. (2006). Human resource management (6th ed.). Boston, MA: Houghton Mifflin Company.

[24] Goldhaber, G. M. (1986). Organizational communication. Jakarta : Erlangga.

[25] Hannegan, C. (2004). Employees as reputation makers. Strategic Communication Management, 8(6), 5.

[26] Hardaker, S. \& Fill, C. (2005). Corporate services brands: The intellectual and emotional engagement of employees. Corporate Reputation Review, 7(4), 365-376.

[27] Hussami, M. (2008). A study of nurse's job satisfaction: The relationship to organizational commitment, perceived organizational support, transactional leadership, transformational leadership and level of education. European Journal of Scientific Research, 22(2), 286-295.

[28] Kular, S., Gatenby, M., Rees, C., Soane, E., \& Truss, K. (2008). Employee engagement: A literature review. Working Paper Series. KingstonBussiness School, 1-33.

[29] Markos, S., \& Sridevi, M.S. (2010). Employee engagement: The key to improving performance. International Journal of Bussiness and Management, 5, 89-96.

[30] Matell, M. S., \& Jacoby, J. (1972). Is there an optimal number of alternatives for likert scale effects of tesing time and scale properties? Effects of testing time and scale properties. Journal of Applied Psychology, 56(6), 506-509.
[31] Miao, R., Kim, H. (2010). Perceived Organizational Support, Job Satisfaction and Employee Performance: An Chinese empirical study. Journal of Service science and Management, 3, 257-264.

[32] Ram, P., \& Prabhakar, G. (2011). The role of employee engagement in work-related outcomes. Interdisciplinary Journal of Research in Business, 1(3), 47-61.

[33] Rhoades, L., \& Eisenberger, R. (2002). Perceived organizational support. A review of the literature. Journal of Applied Psychology, 87(4), 698-714.

[34] Rhoades, L., Eisenberger, R., \& Armeli, S. (2001). Affective commitment to the organization: The contribution of perceived organizational support. Journal of Applied Psychology, 86, 825-836.

[35] Rich, B. L., Lepine, J. A. \& Crawford, E. R. (2010). Job engagement: Antecedents and effects on job performance. Academy of Management Journal, 53, 617-635.

[36] Robinson, D., Perryman, S., \& Hayday, S. (2004). The drivers of employee engagement. UK: The Institute for Employment Studies.

[37] Rubel, M. R. B. \& Kee, D. M. H. (2013). Perceived support and employee performance: The mediating role of employee engagement. Life Science Journal, 10, 2557-2567.

[38]Ruck, K. (2012). Developing Internal Communication Practice That Supports Employee Engagement. Diunduh dari http://www.pracademy.co.uk/wpcontent/uploads/2012/07/DevelopingInternal-Communication-Practice-ThatSupports-Employee-Engagement-July2012.pdf.

[39]Saks, A. (2006). Antecedents and consequences of employee engagement. Journal of Managerial Psychology, 21(7), 600619.

[40] Shore, L. M., \& Shore, T. H. (1995). Perceived organizational support and organizational justice. In R. S. Cropanzano \& K. M. Kacmar (Eds.), Organizational politics, justice, and support: Managing the social climate of the workplace (pp. 149-164). Westport, CT: Quorum.

[41] Schaufeli, W. \& Bakker, A. (2004). Utrecht work engagement scale. Utrecht University: Occupational Health Psychology Unit.

[42] Schaufeli, W. B. \& Bakker, A. B. (2004). Job demands, job resources, and their relationship with burnout and engagement: 
A multi-sample study. Journal of Organizational Behavior, 25, 293-315.

[43] Sudhakar, B., \& Patil, S. (2006). Measuring up.Communication World, 32-35.

[44] Taylor, M., \& Elsey, G. (2005). Building commitment to a new business strategy at sensis. Strategic Communication Management, 9, 14-17.

[45] Thomson, K. \& Hecker, L. (2000). Valueadding communication: Innovation in employee communication and internal marketing. Journal of Communication, 5(1), 48-58.

[46] Truss, C., Soane, E., Edwards, C., Wisdom, K., Croll, A., \& Burnett, J. (2006). Working life: Employee attitudes and engagement. London: Chartered Institute of Personnel and Development.

[47] Tsang, K.K. (2012). The use of midpoint on likert scale: The implications for educational research. Hong Kong Teacher's Centre Journal, 11, 121-130.
[48] Tucker, M. L., Meyer, G. D., \& Westerman, J. W. (1996). Organization communication: Development of internal strategic competitive advantage. Journal of Business Communication, 33(1), 51-69.

[49] Watson Wyatt Worldwide. (2007). Playing to win in a global economy: Global strategic rewards report and United States findings. Towers Watson, 1-24.

[50] Watson Wyatt Worldwide. (2013). Change and Communication ROI Study Report. How the fundamentals have evolved and the best adapt. Towers Watson, 1-13.

[51] White, C., Vanc, A., \& Stafford, G. (2010). Internal communication, information satisfaction and sense of community: The effect of personal influence. Journal of Public Relations Research, 22, 65-84.

[52] Yates, K. (2006). Internal communication effectiveness enhances bottom-line results. Journal Of Organizational Excellence, 10, 7179. 